\title{
COOPERATIVENESS, IMPLICATURE, AND NEO-GRICEAN PRAGMATICS IN TIM O'BRIEN'S WORKS
}

\section{Dina Ahmed Ahmed Sultan}

Assistant Lecturer at the Department of English

Faculty of Arts- Mansoura University

$$
\begin{aligned}
& \text { بسلط هذا البحث الضوء علي نظرية التعاون، والمضمون، وبر/جماتية جرايس الحدبثة وتطبيق هذه القضايا على } \\
& \text { بعض الأمثلة من روايات تبم أوبراين. } \\
& \text { حظ الباحث أن الهتحثثين بعنون أكثر مدا يقولون و أن أكثر الأنواع السائدة من عدم الالتنزام بدبادئ المضدون } \\
& \text { اللغوي عند Grice (جرابس) هي عدم الالتز ام بمبدأ الكمبة وعدم الالتز ام بمبدأ العلاقة. }
\end{aligned}
$$

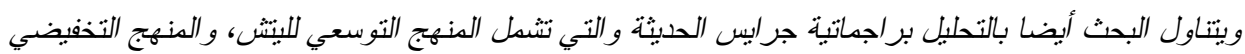

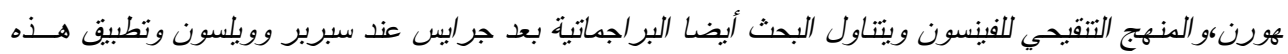

$$
\begin{aligned}
& \text { القضايا على بعض الأمثلة من روايات تيم أوبراين. }
\end{aligned}
$$

Abstract

The present research sheds light on cooperativeness, implicatures, and Neo-Gricean pragmatics and applying them on some representative extacts from Tim O'Brien's novels.

From Tim O'Brien's extracts under study, The researcher noted that speakers frequently mean much more than their words actually say, i.e. more is being communicated than is said.

Grice's theory is an attempt at explaining how a hearer gets from what is said to what is meant, from the level of expressed meaning to the level of implied meaning.

From the previous excerpts, it is obvious that the most prevalent type of flouting of the maxims in Tim O'Brien's novels is that of quantity and relation.

\section{Introduction:}

The focus of this research has been the work of Grice, and subsequent work within pragmatics which has sought to extend, develop or amend his ideas and applying it on Tim O'Brien's novels.

H. P. Grice had worked with J. L. Austin at Oxford in the 1940s and 1950s and his work on the Cooperative Principle arises from the same tradition of ordinary language philosophy. Like Austin before him, Grice was invited to give the William James lectures at Harvard University, and it was there in 1967 that he first outlined his theory of implicature (a shorter version of which was published in 1975 in a paper "Logic and conversation". In papers published in 1978 and 1981 Grice expanded upon this earlier work, but he never fully developed his theory - there are many gaps and several inconsistencies in his writings.

Grice's theory is an attempt at explaining how a hearer gets from what is said to what is meant, from the level of expressed meaning to the level of implied meaning.

\section{Implicature:}

Grice (1975) distinguished two different sorts of implicature: conventional implicature and conversational implicature. They have in common the property that they both convey an additional level of meaning, beyond the semantic meaning of the words uttered. They differ in that in the case of conventional implicature the same implicature is always conveyed, regardless of context, whereas in the case of conversational implicature, what is implied varies according to the context of utterance. 


\subsection{Conventional Implicature:}

There are comparatively few examples of conventional implicatures; Stephen C. Levinson (1992, p. 127) lists four: but, even, therefore and yet, Thomas (57) adds some uses of for, as in: she plays chess well, for a girl. The following is an example of conventional implicature which is quoted from Thomas (1995, p. 57):

(1) ... she was cursed with a stammer, unmarried but far from stupid.'

Although it is not actually asserted that unmarried people (or, perhaps, people who stammer) are stupid, the word but definitely implies that this is the case. The word but carries the implicature that what follows will run counter to expectations this sense of the word but always carries this implicature, regardless of the context in which it occurs. And in everyday life, people readily respond to such conventional implicatures.

\section{The Cooperative Principle and the Four Conversational Maxims:}

In order to explain the mechanisms by which people interpret conversational implicature, in "Logic and Conversation" Grice (1975) introduced four conversational maxims and the Cooperative Principle (CP). The CP runs as follows:

"Make your conversational contribution such as is required, at the stage at which it occurs, by the accepted purpose or direction of the talk exchange in which you are engaged" (p. 45).

Also, in "Logic and Conversation" Grice (45-6) proposed four maxims, the maxims of Quantity, Quality, Relation and Manner, which were formulated as follows: Quantity:

1 - Make your contribution as informative as is required (for the current purposes of the exchange).

2 - Do not make your contribution more informative than is required.

Quality: Try to make your contribution one that is true.
1 - Do not say what you believe to be false.

2 - Do not say that for which you lack adequate evidence.

Relation: Be relevant.

Manner: Be perspicuous.

1 - Avoid obscurity of expression.

2 - Avoid ambiguity.

3 - Be brief (avoid unnecessary prolixity).

4 - Be orderly.

McCready (2015) notes that: "the upshot is that cooperativity cannot be viewed as a general normative principle, but instead that it is a purely contingent matter, at least for the whole spectrum of human behavior" (p. 19).

\section{Hedges:}

The importance of the maxim of quality for cooperative interaction in English may be best measured by the number of expressions we use to indicate that what we are saying may not be totally accurate. The initial phrases in (2a-c) and the final phrase in (2d) are notes to the listener regarding the accuracy of the main statement.

(2) (a) As far as I know, they're married.

(b) I may be mistaken, but I thought I saw a wedding ring on her finger.

(c) I'm not sure if this is right, but I heard it was a secret ceremony in Hawaii.

(d) He couldn't live without her, I guess. (qtd. from Yule, 2008, p. 38)

The conversational context for the examples in (2) might be a recent rumor involving a couple known to the speakers. Cautious notes, or hedges, of this type can also be used to show that the speaker is conscious of the quantity maxim, as in the initial phrases in (3a-c), produced in the course of a speaker's account of her recent vacation.

(3) (a) As you probably know, I am terrified of bugs.

(b) So, to cut a long story short, we grabbed our stuff and ran. 
(c) I won't bore you with all the details, but it was an exciting trip.

(qtd. from Yule, 2008, p. 38)

Markers tied to the expectation of relevance (from the maxim of relation) can be found in the middle of speakers' talk when they say things like 'Oh, by the way' and go on to mention some potentially unconnected information during a conversation. Speakers also seem to use expressions like 'anyway' or 'well, anyway', to indicate that they may have drifted into a discussion of some possibly non-relevant material and want to stop. Some expressions which may act as hedges on the expectation of relevance are shown as the initial phrases in $(4 a-c)$, from an office meeting.

(4) (a) I don't know if this is important, but some of the files are missing.

(b) This may sound like a dumb question, but whose hand writing is this?

(c) Not to change the subject, but is this related to the budget?

(qtd. from Yule, 2008, p. 39)

The awareness of the expectations of manner may also lead speakers to produce hedges of the type shown in the initial phrases in (5a-c), heard during an account of a crash.

(5) (a) This may be a bit confused, but I remember being in a car.

(b) I'm not sure if this makes sense, but the car had no lights.

(c) I don't know if this is clear at all, but I think the other car was reversing.

(qtd. from Yule, 2008, p. 39)

All of these examples of hedges are good indications that the speakers are not only aware of the maxims, but that they want to show that they are trying to observe them. Perhaps such forms also communicate the speakers' concern that their listeners judge them to be cooperative conversational partners.

There are, however, some circumstances where speakers may not follow the expectations of the cooperative principle. In courtrooms and classrooms, witnesses and students are often called upon to tell people things which are already well-known to those people (thereby violating the quantity maxim). Such specialized institutional talk is clearly different from conversation.

However, even in conversation, a speaker may 'opt out' of the maxim expectations by using expressions like 'No comment' or 'My lips are sealed' in response to a question. An interesting aspect of such expressions is that, although they are typically not 'as informative as is required' in the context, they are naturally interpreted as communicating more than is said (i.e. the speaker knows the answer). This typical reaction (i.e. there must be something 'special' here) of listeners to any apparent violation of the maxims is actually the key to the notion of conversational implicature.

\section{Conversational Implicature:}

The basic assumption in conversation is that, unless otherwise indicated, the participants are adhering to the cooperative principle and the maxims.

In example (6), Dexter may appear to be violating the requirements of the quantity maxim.

(6) Charlene: I hope you brought the bread and the cheese.

Dexter: Ah, I brought the bread.

(qtd. from Yule, 2008, p. 40)

After hearing Dexter's response in (6), Charlene has to assume that Dexter is cooperating and not totally unaware of the quantity maxim. But he didn't mention the cheese. If he had brought the cheese, he would say so, because he would be adhering to the quantity maxim. He must intend that she infer that what is not mentioned was not brought. In this case, 
Dexter has conveyed more than he said via a conversational implicature.

\subsection{Generalized Conversational Implicatures:}

In the case of example (6), no special background knowledge of the context of utterance is required in order to make the necessary inferences. The same process of calculating the implicature will take place if Doobie asks Mary about inviting her friends Bella and Cathy to a party, as in (7a), and gets the reply in (7b). The context is different from (6), but the general process of identifying the implicature is the same.

(7) (a) Doobie: Did you invite Bella and Cathy?

(b) Mary: I invited Bella. (qtd. from Yule, 2008, p. 40)

When no special knowledge is required in the context to calculate the additional conveyed meaning, it is called a generalized conversational implicature. One common example in English involves any phrase with an indefinite article of the type 'a/anX', such as 'a garden' and 'a child' as in (8). These phrases are typically interpreted according to the generalized conversational implicature.

(8) I was sitting in a garden one day. A child looked over the fence.

The implicatures in (8), that the garden and the child mentioned are not the speaker's, are calculated on the principle that if the speaker was capable of being more specific (i.e. more informative, following the quantity maxim), then he or she would have said 'my garden' and 'my child'.

A number of other generalized conversational implicatures are commonly communicated on the basis of a scale of values and are consequently known as scalar implicatures.

\subsubsection{Scalar Implicaures:}

Certain information is always communicated by choosing a word which expresses one value from a scale of values. This is particularly obvious in terms for expressing quantity, as shown in the scales in (9), where terms are listed from the highest to the lowest value.

(9) all, most, many, some, few

always, often, sometimes

When producing an utterance, a speaker selects the word from the scale which is the most informative and truthful (quantity and quality) in the circumstances, as in (10) which is quoted from Yule (2008, p. 41):

(10) I'm studying linguistics and I've completed some of the required courses.

By choosing 'some' in (10), the speaker creates an implicature (not all). This is one scalar implicature of uttering (10). The basis of scalar implicature is that, when any form in a scale is asserted, the negative of all forms higher on the scale is implicated. The first scale in (9) had 'all', 'most', and 'many', higher than 'some'. Given the definition of scalar implicature, it should follow that, in saying 'some of the required courses', the speaker also creates other implicatures.

\subsection{Particularized Conversational Implicatures:}

In the preceding examples, the implicatures have been calculated without special knowledge of any particular context. However, most of the time, our conversations take place in very specific contexts in which locally recognized inferences are assumed. Such inferences are assumed. Such inferences are required to work out the conveyed meanings which result from particularized conversational implicatures. As an illustration, consider example (11), where Tom's response does not appear on the surface to adhere to relevance. (A simply relevant answer would be 'Yes' or 'No'.) 
(11) Rick: Hey, coming to the wild party tonight?

Tom: My parents are visiting.

(qtd. from Yule, 2008, p. 43)

In order to make Tom's response

relevant, Rick has to draw on some assumed knowledge that one college student in this setting expects another to have. Tom will be spending that evening with his parents, and time spent with parents is quiet (consequently Tom is not at party).

Because they are by far the most common, particularized conversational implicatures are typically just called implicatures.

\section{Observing the Maxims:}

The least interesting case is when a speaker observes all the maxims as in the following example which is quoted from Thomas (1995, p. 64):

(12) Husband: Where are the car keys?

Wife: They're on the table in the hall.

The wife has answered clearly (Manner) truthfully (Quality), has given just the right amount of information (Quantity) and has directly addressed her husband's goal in asking the question (Relation). She has said precisely what she meant, no more and no less, and has generated no implicature(i.e. there is no distinction to be made here between what she says and what she means, there is no additional level of meaning).

\section{Non-observance of the Maxims:}

Grice (1975) was well aware, however, that there are very many occasions when people fail to observe the maxims. There are five ways of failing to observe a maxim:

Flouting a maxim

Violating a maxim

Infringing a maxim

Opting out of a maxim

Suspending a maxim

People may fail to observe a maxim because, for example, they are incapable of speaking clearly, or because they deliberately choose to lie.

The most important category by far, the one which generates an implicature, is the first, which is flouting a maxim.

\section{Flouting a Maxim:}

The situations which chiefly interested Grice were those in which a speaker blatantly fails to observe a maxim, not with any intention of deceiving or misleading, but because the speaker wishes to prompt the hearer to look for a meaning which is different from, or in addition to, the expressed meaning. This additional meaning he called 'conversational implicature' and he termed the process by which it is generated 'flouting a maxim'.

A flout occurs when a speaker blatantly fails to observe a maxim at the level of what is said, with the deliberate intention of generating an implicature.

\section{Problems with Grice's Theory:}

Thomas (1995, pp. 87-8) listed a number of problems associated with Grice's theory which are:

- Sometimes an utterance has a range of possible interpretations. How do we know when the speaker is deliberately failing to observe a maxim and hence that an implicature is intended?

- How can we distinguish between different types of non-observance (e.g. distinguish a violation from an infringement)?

- Grice's four maxims seem to be rather different in nature. What are the consequences of this?

- Sometimes the maxims seem to overlap or are difficult to distinguish from one another.

- Grice argued that there should be a mechanism for calculating implicature, but it is not always clear how this operates.

10. Rethinking Grice: Neo-Gricean Pragmatics: 
Grice (1975) believes the first component of the Quality maxim, "Try to make your contribution one that is true" to be the most important to the extent that 'other maxims come into operation only on the assumption that this maxim of Quality is satisfied'.

Grice also admits to finding his Relation maxim problematic, not least because: ". . . its formulation conceals a number of problems .. . about what different kinds and focuses of relevance there may be, how to allow for the fact that subjects of conversation are legitimately changed, and so on (Grice, 1975, p. 46).

In addition, he suggests that there are all sorts of other maxims such as "Be polite". Researchers have since proposed a number of changes to Grice's theory. In the following sub-sections, the researcher outlines the ideas of three well-known NeoGriceans - Leech, Horn, and Levinson before moving on to discuss the PostGricean approach of Sperbr and Wilson.

\subsection{Leech's Expansionist Approach:}

Geoffrey Leech in Principles of Pragmatics recognizes that the pressure to be polite can be very powerful, to the extent that the Gricean maxims are affected. For example, we might find it rude if, in answer to our greeting, How are you?, our interlocutor merely replied Fine and walked away without returning the greeting. Yet, this answer adheres to the Manner maxim. Leech (1983) also suggests that some flouts of the Gricean maxims are undertaken because of politeness reasons. His argument is that indirectness allows us to convey messages which, because they are ambivalent (i.e. have more than one potential pragmatic force), are arguably less face-threatening than they might have been. We might opt to say to the host, It's hot in here, or even Do you think it's hot in here?, when at a party, rather than request/command our host to open a window, for example. We do so, according to Leech, because such indirect utterances give our targets more freedom (i.e. optionality) in deciding how to respond.

Leech proposed that we therefore complement Grice's Cooperative Principle (CP) with a Politeness Principle (PP) and six interpersonal politeness maxims (tact, generosity, approbation, modesty, agreement, sympathy).

\subsection{Horn's Reductionist Approach:}

Laurence R. Horn (1984, p. 12) represents our second Neo-Gricean approach. Like Grice, he ascribes a privileged status to the Quality maxim, such that it becomes a kind of felicity condition for all implicatures - on the assumption that it is hard to see how any of the other maxims can be satisfied without it being observed. But he reduces the other Gricean maxims to 'two antithetical principles of pragmatic inference', the $\mathrm{Q}$ principle and the R Principle:

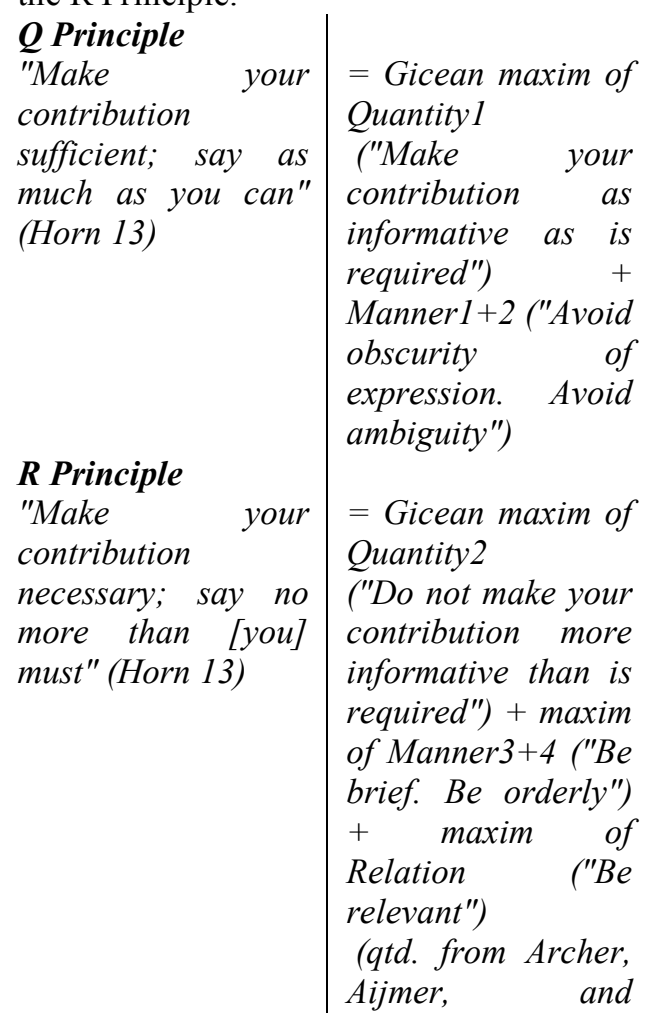


Wichmann, 2012, p. 55)

The Q Principle is deliberately hearer-based: it centres on the assumption that the speaker will provide sufficient information for the hearer. Hence, if some is as much as the speaker can say, the hearer should take it that the speaker implies not all (unless he is given evidence to the contrary). Similarly, may should be taken to mean 'permitted but not obligated to'. You will notice that we have drawn our examples from the scalar implicature relating to quantifiers (all, most, many, some) and the scalar implicature relating to modals (must, should, may). This is deliberate, as Horn's Q Principle provides us with an excellent means of explaining the phenomenon of scalar implicature. Indeed, we use the term 'Horn scale', within the field of pragmatics, to explain a number of alternative sets (including numbers, colours, etc.).

In contrast to the $\mathrm{Q}$ Principle, Horn's R Principle is oriented to reducing the speaker's effort, and centres on the assumption that the speaker should say no more than is necessary to achieve his/her goals, because his/her minimal forms will invite pragmatic strengthening (i.e. inferences).

\subsection{Levinson's Revisionist Approach}

Archer, Aijmer, and Wichmann (2012, pp. 55-6) note that Levinson in his article "Three Levels of Meaning" argues for a revision - as well as a reduction - of the Gricean maxims. His first step involves refining Grice's distinction between 'what is said' and what is conveyed. He did so by distinguishing three levels of meaning:

- Entailment, that is, meaning which is derived from/involves truth relations;

- utterance-type meaning, that is, default interpretations which are inferable without having to draw on contextual cues; and
- utterance-token meaning, that is, contextsensitive interpretations.

Levinson has since suggested that utterance-type meaning can be accounted for via three heuristics related to Grice's Quantity and Manner maxims, namely: H1 (cf. Quantity1): What isn't said, isn't. H2 (cf. Quantity2): What is simply described is stereotypically exemplified. H3 (cf. Manner): What's said in an abnormal way, isn't normal.

(Archer,Aijmer, and Wichmann,2012,p. 56). These heuristics, in turn, have formed the basis for three Neo-Gricean principles; the Q-Principle (Quantity), the IPrinciple (Informativeness) and the MPrinciple (Manner). As the descriptions below reveal, the Q- and I-Principles broadly correspond to Horn's Q and R Principles as well as various aspects of Grice's Quantity and Manner maxims. The M-Principle has been included by Levinson as a means of dealing with marked inference, and thus also overlaps with Girce's Manner maxim:

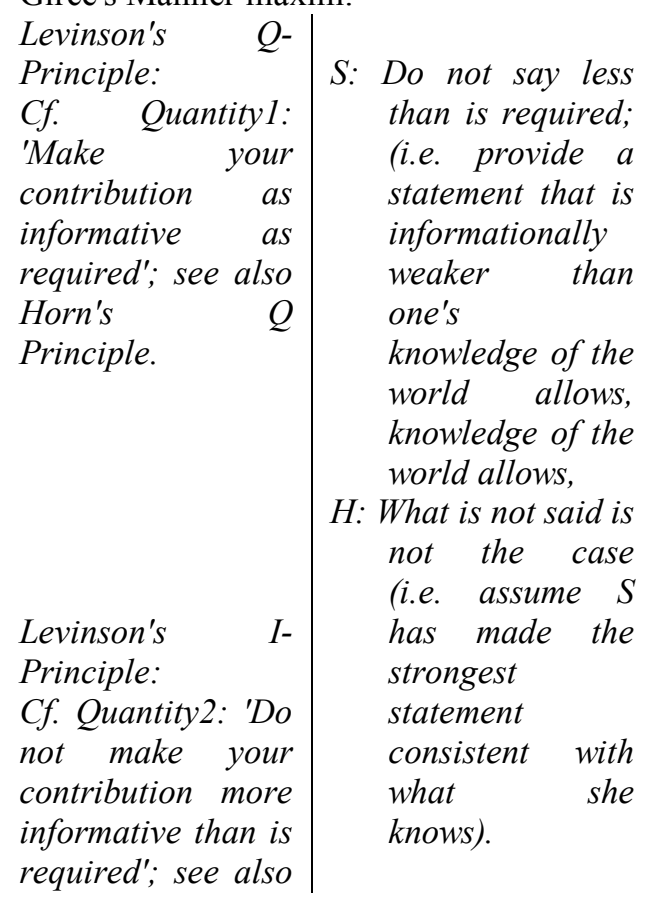




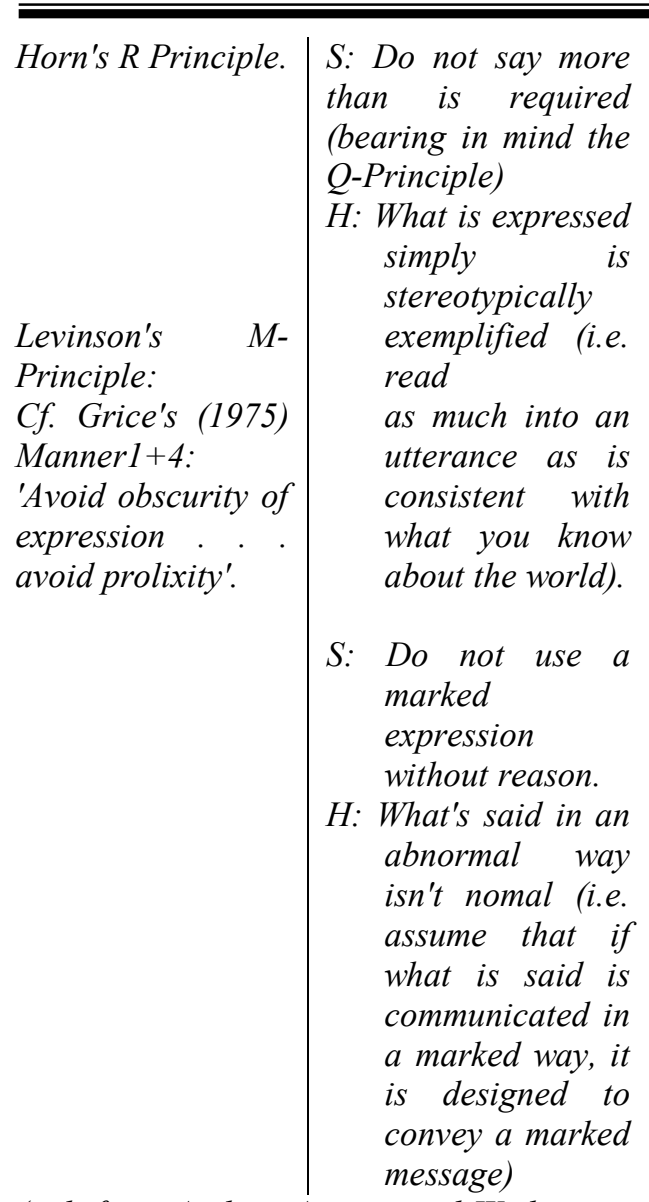

(qtd. from Archer, Aijmer, and Wichmann, 2012, pp. 56-7)

One thing to notice, here, is that Levinson's Q-, I- and M-Principles contain both a speaker and hearer component (like Horn's). The hearer components of the Qand I-Principles have proven to be particularly useful, as they can explain why stereotypical (or taken-for-granted) aspects of meanings can be left implicit. I cut a finger, for example, will be taken to mean the speaker has cut his/her own finger (unless interlocutors are given evidence which contradicts this assumption).

Interestingly, Levinson suggests that the Q-, I- and M-Principles give rise to Q-, I- and M-implicatures respectively, but that Q- and M-implicatures will have priority over any I-implicatures.

\subsection{Sperber and Wilson's Post-Gricean Pragmatics:}

Sperber and Wilson go much further than the Neo-Griceans have done in revising Grice's ideas. They propose that all of the Gricean maxims be reduced to one, that of Relation, on the assumption that relevance is a natural feature of all successful communication. Indeed, they argue that: "communicators do not 'follow' the principle of relevance; and they could not violate it even if they wanted to. The principle of relevance applies without exceptions" (Sperber and Wilson, 1995,p. 162)

This proposal is more innovative than it might first appear, as relevance theoretic pragmatics assumes a very different view of what pragmatics is and what it entails than Grice and the NeoGriceans. For example, whereas the latter account for the derivation of implicatures using an inductive, rationalistic perspective (and hence focus on what interlocutors most probably mean in context), relevance theorists seek to explain what actually goes on in hearers' minds, using deductive means. They argue, for example, that as relevance is a given, interlocutors will treat the context as the variable (Sperber and Wilson, 1995, p. 142). Moreover, in Processing the relevance of an utterance, in context X, they will identify (what they take to be) S's communicative intention by construing (what they hope will be) an accurate representation of it in their minds. A consistent inability to construct such mental representations, moreover, may be taken to constitute some kind of pathological condition; this helps to explain why many relevance theorists are interested in experimental tests and studies of communication pathologies.

Relevance Theory is based on a broad understanding of relevance and two 
Principles of Relevance. Relevance is said to encompass "all external stimuli or internal mental representations capable of providing an input to cognitive processes, including sights, smells, utterances, thoughts, memories or conclusions of inferences" (Wilson, 2010, p. 394). The first of the two principles - the Cognitive Principle - refers to cognition on a general level: "Human cognition tends to be geared to the maximisation of relevance" (Sperber and Wilson, 1995, p. 260). The second principle - the Communicative Principle comes about because of the first, and is specific to communication (as its name implies). It captures the notion that interlocutors, by communicating something, are implicitly asserting they have something pertinent to communicate: "Every act of ostensive communication communicates a presumption of its own optimal relevance" (Sperber and Wilson, 1995, p. 260).

The presumption of 'optimal relevance' does not mean that every utterance has the same degree of relevance for an addressee. Rather, it means that addressees will use the minimum necessary effort to obtain the most relevant interpretation, implicature or 'contextual effect'.

10.5 The Role of $S$ and $H$ in Meaning Making:

Sperber and Wilson view communication in terms of cognitive environment (i.e. the set of facts that are manifest to an individual) and mutual manifestness (i.e. the set of potential assumptions that individuals are capable of perceiving and inferring as a result of an ostensive stimulus). Mutual manifestness, in particular, involves interlocutors' dynamically processing contextual cues 'online' as and when they occur. As the following quotation reveals, however, Sperber and Wilson (1995) believe that S has more communicative responsibility than does $\mathrm{H}$ :
It is left to the communicator to make correct assumptions about the codes and contextual information that the audience will have accessible and be likely to use in the comprehension process. The responsibility for avoiding misunderstandings also lies with the speaker, so that all the hearer has to do is go ahead and use whatever code and contextual information comes most easily to hand (p. 43).

The responsibility that Sperber and Wilson give to $\mathrm{S}$ is understandable, in view of their stance that $\mathrm{H}$ always assumes $\mathrm{S}$ is trying to be optimally relevant. However, it gives the impression that the roles of $\mathrm{S}$ and $\mathrm{H}$ are 'fixed' when, in reality, they are transient and continually interchanging - in both everyday conversation and institutional interaction. Moreover, speakers and hearers both play an active part in coconstructing the discourse. That is to say, $\mathrm{H}$ evaluates/provides feedback to $\mathrm{S}$ which, in turn, may determine S's next move. Some cognitive linguists have thus proposed an alternative cognitive pragmatics approach to relevance theory which acknowledges 'the combined effort of an actor and a partner' who "consciously and intentionally cooperate to construct together the shared meaning of their interaction" (Bara, 2010, p. 51). Arundale (2008, p. 243) goes further still: he proposes that we reject Griceaninfluenced approaches altogether (because of their focus on H's successful recognition of S's intention and, latterly, on H's attribution of intent) and adopt, instead, a model which considers 'utterances in sequence' and focuses, specifically, on $\mathrm{S}$ and H's ongoing process of 'confirming and modifying' interconnected interpretings and their (potential) 'proactive and retroactive effects'.

11. Conversational Implicatures in Tim O'Brien's The Things They Carried:

"Henry Dobbins asked what the moral was. 
Moral?

You know. Moral.

Sanders wrapped the thumb in toilet paper and handed it across to Norman Bowker. There was no blood. Smiling, he kicked the boy's head, watched the flies scatter, and said, It's like with that old TV show Paladin. Have gun, will travel.

Henry Dobbins thought about it.

Yeah, well, he finally said. I don't see no moral.

There it is, man.

Fuck off" (O'Brien, 1991, p. 12).

In the following example Mitchell Sanders is flouting the maxim of relation in his answer to Henry Dobbins question about moral he replied "Moral" which is very obviously irrelevant to the topic in hand.

"Like when Ted Lavender went too heavy on the tranquilizers.

'How's the war today?' somebody would say, and Ted Lavender would give a soft, spacey smile and say, 'Mellow, man. We got ourselves a nice mellow war today.' " (O'Brien, 1991, p. 32)

In this quotation Ted Lavender is flouting the maxim of quality by saying that war is "a nice mellow war today" which is untrue since he is under the effect of tranquilizers.

" 'Dinner at five-thirty,' he said. 'You eat fish?'

'Anything,' I said.

Elroy grunted and said, 'I'll bet.' " (O'Brien, 1991, p. 46)

In this example the speaker (the author) is flouting the maxim of quantity. He gives less information than the situation requires when he answers "Anything".

"'You know what we forgot?' he said. 'We forgot wages. Those odd jobs you done. What we have to do, we have to figure out what your time's worth. Your last job - how much did you pull in an hour?'

'Not enough,' I said.

'A bad one?'
'Yes. Pretty bad.' " (O'Brien, 1991, p. 49)

In the following quotation the speaker (the author) is flouting the maxim of quality because he said that the job is "Pretty bad" which is untrue.

" 'Right,' I said.

'Understand me?'

'Invisible.'

Sanders nodded" (O'Brien, 1991, p. 71).

In the following example the speaker (the author) is flouting the maxim of relation when he said "Invisible" as an answer to "Understand me" which is an irrelevant answer to that question.

"How do you generalize?

War is hell, but that's not the half of it, because war is also mystery and terror and adventure and courage and discovery and holiness and pity and despair and longing and love. War is nasty; war is fun. War is thrilling; war is drudgery. War makes you a man; war makes you dead" (O'Brien, 1991, p. 77).

In this quotation Dave Jensen is flouting the maxim of quantity. He gives more information than is required.

$$
\text { "'Yeah.' }
$$

'You ever feel that?'

'Sort of.'

Kiowa made a noise in his throat. 'This is all wrong,' he said. 'What?'

'Setting up here. It's wrong. I don't care what, it's still a church.'

Dobbins nodded. 'True.'" (O'Brien, 1991, p. 117)

In this example Kiowa is flouting the maxim of relation. His answer "Setting up here. It's wrong. I don't care what, it's still a church" is an irrelevant answer to the question "What?".

"And then he would have talked about the medal he did not win and why he did not win it.

'I almost won the Silver Star,' he would have said. 
'How's that?'

'Just a story.' " (O'Brien, 1991, p. 142)

In the following example Norman

Bowker is flouting the maxim of relation.

His answer "Just a story" is an irrelevant answer to the question "How's that?".

"If she were here with him, in the car, she would've said, 'Stop it.

I don't like that word.'

'That's what it was.'

'All right, but you don't have to use that word.'

'Fine. What should we call it?'

She would have glared at him. 'I don't know. Just stop it.' " (O'Brien, 1991, p. 145)

In this quotation Sally Kramer is flouting the maxim of relation in her answer "I don't know. Just stop it" which is an irrelevant answer to the question "What should we call it?".

" 'The truth,' Norman Bowker would've said, 'is I let the guy go.'

'Maybe he was already gone.'

'He wasn't.'

'But maybe.'

'No, I could feel it. He wasn't. Some things you can feel.' " (O'Brien, 1991, p. 151)

In the following quotation Norman Bowker is flouting the maxim of manner when he said "No, I could feel it. He wasn't. Some things you can feel." which is so long and not brief.

"'A classic case,' Azar was saying. 'Biting the dirt, so to speak, that tells the story.'

'Enough,' Bowker said.

'Like those old cowboy movies. One more redskin bites the dirt.'

'I'm serious, man. Zip it shut.'

Azar smiled and said, 'Classic.' " (O'Brien, 1991, p. 165)

In this example Azar is flouting the maxim of relation when he said "Classic" which is irrelevant to the topic in hand.
Norman Bowker stared down at the rucksack. It was made of dark green nylon with an aluminum frame, but now it had the curious look of flesh.

'It wasn't the LT's fault,' Bowker said quietly.

'Whose then?'

'Nobody's. Nobody knew till afterward.' " (O'Brien, 1991, p. 166)

In the following example Norman Bowker is flouting the maxim of quantity. $\mathrm{He}$ gives more information than the situation requires by saying "Nobody's. Nobody knew till afterward".

"Norman Bowker found Kiowa. He was under two feet of water. Nothing showed except the heel of a boot.

'That's him?' Azar said.

'Who else?'

'I don't know.' Azar shook his head. 'I don't know.'

Norman Bowker touched the boot, covered his eyes for a moment, then stood up and looked at Azar.

'So where's the joke?' he said.

'No joke.'

'Eating shit. Let's hear that one.'

'Forget it.' " (O'Brien, 1991, p. 171)

In this quotation Norman Bowker is flouting the maxim of relation. His answer "Who else?" is very obviously irrelevant to the topic in hand.

12. Conversational Implicatures in Tim O'Brien's Going After Cacciato:

" "I never seen rain like this. You ever? I mean, ever?"

"No," Paul Berlin said."Not since yesterday."

"And I guess you're Cacciato's buddy. Is that the story?"

"No, sir," Paul Berlin said. "Sometimes he'd tag along. Not really."

"Who's his buddy?"

"Nobody. Maybe Vaught. I guess Vaught was, sometimes." " (O'Brien, 1978, p. 4) 
In the following quotation Paul Berlin is flouting the maxim of quantity. He gives more information than is required by saying "Nobody. Maybe Vaught. I guess Vaught was, sometimes".

" "Yeah."A long silence. "What time is it?" "Two?"

"What time you got, sir?"

"Very lousy late, "said the lieutenant from the bushes.

"Come on, what-"

"Four o'clock. Zero-four-hundred. Which is to say a.m." " (O'Brien, 1978, p. 13)

In this example Paul Berlin is

flouting the maxim of quantity. He gives more information than the situation requires by saying "Four o'clock. Zero-fourhundred. Which is to say a.m".

"The red dotted line crossed the border into Laos.

Farther ahead they found Cacciato's armored vest and bayonet, then his ammo pouch, then his entrenching tool and ID card.

"Why?" the lieutenant muttered.

"Sir?"

"Why? Tell me why."The old man was speaking to a small pine.

"Why the clues? Why don't he just leave the trail? Lose us, leave us behind? Tell me why."

"A rockhead," said Stink Harris. "That's why." " (O'Brien, 1978, p. 17)

In this quotation Stink Harris is

flouting the maxim of relation. His answer

"A rockhead, that's why" is very obviously irrelevant to the topic in hand.

"Whoever was bawling was still bawling. It was like a baby's wail, high and angry.

"Lash L. LaRue. You see them reactions? You see?"

The clearing gleamed. The dead buffalo was bleeding. The living buffalo kept trying to run. It would get to its feet, stumble, struggle for a moment, and then fall. "Like lightning, man! Zip, zap!"
It was a woman's bawling. It came from somewhere near the cart was splashed with blood" (O'Brien, 1978, p. 51).

In the following example Stink Harris is flouting the maxim of quantity. He gives more information than is required by saying "Like lightning, man! Zip, zap!".

"Frowning the girl looked out over the distant blue hills. "It is a pity," she said. "I am sad to learn that the fighting has spread so far."

He shrugged, pretending not to look at her.

"Has it?"

"What?"

"The war. Has it followed us this far?"

Paul Berlin answered truthfully that he wasn't sure. Opinions varied. According to Doc Peret, no fool, the war was over; if you listened to the lieutenant, the war was still a war. It was hard to be sure.

"Well," the girl sighed."We must go on then. We must keep going until you are sure." " (O'Brien, 1978, p. 57)

In the following quotation Paul Berlin is flouting the maxim of relation when he answered truthfully that he wasn't sure. Opinions varied. According to Doc Peret, no fool, the war was over; if you listened to the lieutenant, the war was still a war. It was hard to be sure which is irrelevant to the topic in hand.

" "Negative."The lieutenant looked away. "Say again, this is no friggin' party. No party, no civilians. Next ville, we drop them off and that's the end of it."

"Just dump them?"

"War's a nasty thing."

"Not even-?"

"No."The old man sighed. "No." " (O'Brien, 1978, p. 59)

In this example Lieutenant Corson is flouting the maxim of relation. His answer "War's a nasty thing" is an irrelevant answer to the question "Just dump them?"

"The little man pushed a series of buttons. The periscope whined and began to rise. 
When it clicked into position, he pulled up a stool and motioned for Paul Berlin to look. "What is it?"

"Ah," said Li Van Hgoc. "You don't know?"

Peering into the viewing lens, squinting to see better, Paul Berlin couldn't be sure. Several men appeared to be grouped around the mouth of a tunnel. The forms were fuzzy. Some of them were talking, others silent. One man was on his hands and knees, leaning part way down into the hole" (O'Brien, 1978, p. 87).

In this quotation Li Van Hgoc is flouting the maxim of relation when he said "Ah. You don't know?" which is irrelevant to the topic in hand.

" "You don't smell it?"

They huddled together in a small mud hootch on the outskirts of the ville. The place was deserted. No people and no chickens and no dogs. It was emptiness, but it was lived-in emptiness, emptiness recently vacated, and this made them fidgety. It was an odd-numbered day.

"That fucking smell," Buff said quietly. "I don't like it."

"You win some, you lose some."

"I guess."

"And some get rained out." " (O'Brien, 1978, p. 103)

In the following example Buff is flouting the maxim of quantity. He gives more information than the situation requires by saying "That fucking smell, I don't like it".

"Oscar and Eddie clapped him on the back, and the PFC shrugged and said it happened sometimes.

"What can you do?" Oscar said.

"Yeah."

"Maybe .. . Who knows? Maybe they was out takin' a drive or something. Buying groceries. The world don' stop." " (O'Brien, 1978, p. 159)

In this example the young PFC is flouting the maxim of relation when he said
"Yeah" which is irrelevant to the topic in hand.

" "What's the joke?"

"Wounded," Oscar said.

"What?"

"Wounded. The ol' man, he's among the walkin' wounded, right?" " (O'Brien, 1978, p. 175)

In the following quotation Oscar Johnson is flouting the maxim of relation. His answer "Wounded" is very obviously irrelevant to the topic in hand.

" "He had blue eyes, for Chrissake."

"Who did?"

"Widmark. Widmark got blue eyes. That boy, though-his eyes were brown."

"A murderer," Stink said. I'll bet on it. You wanna bet, Doc?"

"No, I want to drink." " (O'Brien, 1978, p. 188)

In this quotation Oscar Johnson is flouting the maxim of quantity. He gives more information than Stink needs by saying "Widmark. Widmark got blue eyes. That boy, though - his eyes were brown".

" "And passports are therefore unnecessary? Am I understanding correctly?"

"Perfectly," Doc said.

"But you are soldiers?"

"Of a sort."

"Soldiers on leave?"

Doc shrugged. "That's close enough. Touring soldiers." " (O'Brien, 1978, p. 192)

In the following example Doc Peret is flouting the maxim of relation when he said "Of a sort" which is irrelevant to the topic in hand.

"There was a sound beside him, a movement then, "Hey, "then louder, "Hey!" He opened his eyes.

"Hey, we're movin'. Get up."

"Okay."

"You sleeping?"

"No, just resting. Thinking." He could see only part of the soldier's face. It was a 
plump, round, child's face. The child was smiling" (O'Brien, 1978, p. 209).

In this example Paul Berlin is flouting the maxim of quantity. He gives more information than the situation requires by saying "No, just resting. Thinking".

" "Sidney Martin seeks trouble, an' I believe he finally found it."

"You think so, Oscar?"

"I do. I think so." " (O'Brien, 1978, p. 234)

In the following quotation Oscar Johnson is flouting the maxim of quantity. He gives more information than is required by saying "I do. I think so".

" "And then what? What do I say then?"

"I won't do it."

"You think that'll stop them?" " (O'Brien, 1978, p. 239).

In this quotation Cacciato is

flouting the maxim of relation. His answer

"I won't do it" is very obviously irrelevant to the topic in hand.

" "What's the muzzle velocity of a standard AR-15?"

"Two thousand feet a second."

"Who's Secretary of the Army?"

"Stanley Resor."

"Why we fightin' this war?"

"Sir?"

"I say, why we fightin' this fuckin-ass war?"

"I don't_" " (O'Brien, 1978, p. 268).

In the following example Paul

Berlin is flouting the maxim of relation when he said "Sir?" which is irrelevant to the topic in hand.

" "May I wake you?"

He heard a moth playing against a lampshade. His feet tickled.

"Am I being gentle, Spec Four?"

"What is it?" " (O'Brien, 1978, p. 295).

In this example Paul Berlin (Spec

Four) is flouting the maxim of relation. His answer "What is it?" is very obviously irrelevant to the topic in hand.

13. Conversational Implicatures in Tim

O'Brien's If I Die in a Combat
Zone, Box Me Up and Ship Me

Home:

" "Tell them St. Vith."

"What?"

"St. Vith," I said. "That's the name of this ville. It's right here on the map. Want to look?" " (O'Brien, 1975, p. 5).

In the following quotation the speaker (the author) is flouting the maxim of quantity. He gives more information than the situation requires by saying "St. Vith. That's the name of this ville. It's right here on the map. Want to look?".

" "Surprised them," I said. "Faked 'em right out of their shoes."

"Incoming!"

Men were scrambling. Slow motion, then fast motion, and the whole village seemed to shake.

"Incoming!" It was Barney. He was peering at me, grinning. "Incoming!"

"Nice hollering." " (O'Brien, 1975, p. 7)

In this quotation the speaker (the author) is flouting the maxim of relation when he said "Nice hollering" which is irrelevant to the topic in hand.

" "You like getting shot, for God's sake? You like Charlie trying to chuck grenades into your foxhole? You like that stuff?"

"Some got it, some don't. Me, I'm mad as a hatter."

"Don't let him shit you," Chip said. "That whole thing last night was a fake. They planned it, beginning to end." " (O'Brien, 1975 , p. 25)

In this example Mad Mark is flouting the maxim of relation. His answer "Some got it, some don't. Me, I'm mad as a hatter" is very obviously irrelevant to the topic in hand.

"Bates finished tinkering with the scope and handed it back to Chip.

"That better?"

"Wow."

"What's out there?"

"A peep show," Chip murmured. "Sweet, sweet stuff. Dancing soul sisters." He 
giggled and stared through the scope. "Star light, star light."'"( O'Brien, 1975, p. 29)

In the following example Chip is flouting the maxim of quantity. He gives more information than is required by saying "'A peep show. Sweet, sweet stuff. Dancing soul sisters. Star light, star light".

" "My God, man, you want me to use my men to find mines for you? You mean that?"

"That's affirmative," the track commander radioed back. "The mines are pretty thick.

We've got a mine detector, may as well use it." " (O'Brien, 1975, p. 157)

In the following quotation the track commander is flouting the maxim of quantity. He gives more information than the situation requires by saying "That's affirmative. The mines are pretty thick. We've got a mine detector, may as well use it".

" "Oh, how nice."

"Yes."

"And do you like Sydney? Beautiful city, don't you think?"

"It's great. Anything is great, you know." Anything. She could look like a dachshund" (O'Brien, 1975, p. 184).

In this quotation the nice, handsome young man is flouting the maxim of quantity. He gives more information than is required by saying "It's great. Anything is great, you know".

" "I'm Chieu Hoi, old VC."

"Shit, you save their asses, and they'll fall in love with you," the captain said. "Look, if you do a job and help out, they'll like you just fine. Get their respect, and no sweat. Charlie Company will like you just fine. And your kid will be okay too." " (O'Brien, 1975, p. 189)

In this example the captain is flouting the maxim of quantity. He gives more information than Chieu Hoi needs by saying "Shit, you save their asses, and they'll fall in love with you. Look, if you do a job and help out, they'll like you just fine. Get their respect, and no sweat. Charlie
Company will like you just fine. And your kid will be okay too".

14. Conversational Implicatures in Tim O'Brien's In the Lake of the Woods:

" "So there," she said. "We'll be happy now."

"Happy us," he said.

It was a problem of faith. The future seemed intolerable. There was fatigue, too, and anger, but more than anything there was the emptiness of disbelief"( O'Brien, 2006, p. 4).

In the following example John Wade is flouting the maxim of quality because he said "Happy us" which is untrue.

"Later, Kathy nudged him. "Hey there," she said, "you all right?"

"Perfect," he said.

"You don't seem-"

"No, I'm perfect." " (O'Brien, 2006, p. 18)

In this example John Wade is

flouting the maxim of quality because he said "Perfect" which is untrue.

" "Kath, I'm sorry," he said. "I mean it."

"Fine, you're sorry."

"All right?"

"Sorry, sorry. Never ends." Kathy waited for the young Waitress to scoop up their cups. "Stop blaming me. We lost. That's the truth-we lost."

"It was more than that."

"John, we can't keep doing this."

Wade looked at the revolving clock. "Mr. Monster." (O'Brien, 2006, p. 21)

In the following quotation Kathy Wade is flouting the maxim of quantity. She gives more information than is required by saying "Sorry, sorry. Never ends. Stop blaming me. We lost. That's the truth-we lost".

"John thought it over for several days. "Well, all right," he said, "but it still worries me. Things go wrong. Things don't always last."

"We're not things," Kathy said.

"But it can happen." 
"Not with us."

John shrugged and looked away. He was picturing his father's big white casket. "Maybe so," he said, "but how do we know? People lose each other."' (O'Brien, 2006, p. 32)

In this quotation Kathy Wade is flouting the maxim of relation when she said "We're not things" which is irrelevant to the topic in hand.

" "Is what true?"

"The things they're saying. About you."

"Things?"

"You know." " (O'Brien, 2006, p. 56)

In the following example Kathy

Wade is flouting the maxim of relation. Her answer "You know" is very obviously irrelevant to the topic in hand.

"I'm your wife."

"Right," he said.

"So?"

"So nothing." His voice was quiet, a monotone. He turned up the volume on the $T V$. "It's history, Kath. If you want to trot out the skeletons, let's talk about your dentist." " (O'Brien, 2006, p. 56)

In this example John Wade is flouting the maxim of quantity. he gives more information than is required by saying "So nothing. It's history, Kath. If you want to trot out the skeletons, let's talk about your dentist".

" "Where?" John said.

"Outside. There's a garden."

"It's December. It's Minnesota."

Kathy shrugged. They had been married six years, almost seven. The passion was still there" (O'Brien, 2006, p. 59).

In the following quotation Kathy Wade is flouting the maxim of quantity. she gives more information than John Wade needs by saying "Outside. There's a garden".

" "Kath, listen, I need to tell you this. Something's wrong, I've done things."

"It doesn't matter."

"It does."
She smiled brightly at a spot over his shoulder. "We could catch a movie."

"Ugly things."

"A good movie wouldn't hurt."

"Christ, you're not-" " (O'Brien, 2006, p. 74).

In this quotation John Wade is flouting the maxim of relation. His answer "Ugly things" is very obviously irrelevant to the topic in hand.

" "So how's our good senator?"

"Like a judge," she said. "Sober almost."

"No shit?"

"Better every second." " (O'Brien, 2006, p. 86)

In the following example Ruth Rasmussen is flouting the maxim of quantity. She gives more information than is required by saying "Better every second". " "I say, can she swim?"

"Swim?"

"Your wife."

Wade blinked and nodded. "Yes. Good swimmer." " (O'Brien, 2006, p. 90)

In this example John Wade is flouting the maxim of relation when he said "Swim?" which is irrelevant to the topic in hand.

" "Your wife's a hiker?"

"Sometimes."

"So you waited around?"

"Yes."

"Nothing else?"

"Nothing." " (O'Brien, 2006, p. 122)

In this quotation John Wade is flouting the maxim of relation. His answer "Sometimes" is very obviously irrelevant to the topic in hand.

" "Right fine," Wade said. "Just to be clear, though, Kathy and I had something together. It wasn't so terrible."

"That's not quite the point."

"Which is what?"

Pat seemed to flinch. "We shouldn't talk about it."

"What Point?"

"Let's just_" " (O'Brien, 2006, p. 185) 
In the following quotation Pat (Patricia Hood) is flouting the maxim of relation. Her answer "Let's just-" is very obviously irrelevant to the topic in hand.

" "What about the dead folks?"

"Look, I can't_-"

"Awfully goddamned real to them." Pat swung around and looked at him hard. "You didn't do something?"

"Do?"

"Don't fake it. You know what I mean."

She watched him closely for a few seconds. There were birds in the trees, ripples of sunlight" (O'Brien, 2006, $p$. 186).

In this quotation John Wade is flouting the maxim of relation when he said "Look, I can't—" which is irrelevant to the topic in hand.

" "It'll go away."

"Bullshit it will. At least I didn't kill nobody."

"Good. That's good."

"Yeah, but ... What happened here?"

"The sunlight," Sorcerer said.

"Say again?"

"Eat your chocolate." " (O'Brien, 2006, p. 201)

In the following example John Wade (Sorcerer) is flouting the maxim of relation when he said "The sunlight" which is irrelevant to the topic in hand.

"You hear any murder talk?"

Thinbill took a step backward. He was taller than Calley, and stronger, but he was young.

"No, sir," he said.

"Listen close."

"I don't hear it, sir. Nothing."

"Positive?"

"Yes, sir." " (O'Brien, 2006, p. 211)

In this example Lieutenant Calley is flouting the maxim of relation when he said "Positive?" which is irrelevant to the topic in hand.
"Wade tried to smile but couldn't manage it. "Christ," he said. "What's the point?"

"Sir?"

"Everybody thinks_-" He made himself turn away. "I've had it. A bellyful."

"Poor man," Vinny Pearson said.

"Especially from this one."

"Right, and if I was you-"

"The great albino detective." " (O'Brien, 2006, p. 236)

In the following quotation Vinny Pearson is flouting the maxim of relation when he said "Sir?" which is irrelevant to the topic in hand.

From the previous excerpts, it is obvious that the most prevalent type of flouting of the maxims in Tim O'Brien's novels is that of quantity and relation.

From Tim O'Brien's extracts under study, The researcher noted that speakers frequently mean much more than their words actually say, i.e. more is being communicated than is said

\section{References}

1- Primary Sources:

- O'Brien, T. (1975). If I Die in a Combat Zone, Box Me Up and Ship Me Home. New York: Broadway.

- O'Brien, T. (1978). Going After Cacciato. New York: Broadway.

- O'Brien, T. (1991). The Things They Carried. London: Flamingo.

- O'Brien, T. (2006). In the Lake of the Woods. New York: Mariner.

\section{2- Secondary Sources:}

- Allott, N. (2010). Key Terms in Pragmatics. London: Continuum.

- Arundale, R. B. (2008). Against (Gricean) Intentions the Heart of Human Interaction. Intercultural Pragmatics. 5(2): 229 258.

- Atkinson, J. M. , \& Drew, P. (1979). Order in Court. London: Macmillan. 
- Baktin, M. (1981). The Dialogical Imagination. Austin, TX: University of Texas Press.

- Baktin, M. (1986). Speech Genres and Other Late Essays. Austin, TX: University of Texas Press.

- Bara, B. G. (2010). Cognitive Pragmatics. In L. Cummings, Ed. The Pragmatics Encyclopedia. London and New York: Routledge, 50 - 53.

- Biber, D. , Johansson, S. , Leech, G., Conrad, S., \& Finegan, E. (1999). Longman Grammar of Spoken and Written English. London: Longman.

Blakemore, D. (2006). Discourse Markers. In Laurence R. Horn and Gregory Ward, Eds. The Handbook of Pragmatics. Oxford: Blackwell, 221 240.

- Brown, G. , \& Yule, G. (1993). Discourse Analysis. Cambridge: Cambridge University Press.

- Brown, P. , \& Levinson, S. , C. (1987). Politeness: Some Universals in Language Usage. Cambridge: Cambridge University Press.

- Burton - Roberts, N. (Ed.). (2007). Pragmatics. London: Palgrave Macmillan.

- Carston, R. (2004). Implicature Conversational and Content TruthConditional. 12 August 2017

$<$ www.phon.ucl.ac.uk/home/robyn/pdf/woc $. \mathrm{pdf}>$.

- Carter, R., \& M. McCarthy M. (2006). Cambridge Grammar of English. A Comprehensive Guide. Spoken and Written English Grammar and Usage. Cambridge: Cambridge University Press.

Comrie, B. (1976). Aspect: An Introduction to the Study of Verbal Aspect and Related Problems. Cambridge: Cambridge University Press.
- Crystal, D. (2004). A Dictionary of Linguistics and Phonetics. $5^{\text {th }}$ ed. Malden: Blackwell.

- Davies, B. L. (2007). Grice's Cooperative Principle: Meaning and Rationality. Journal of Pragmatics, 39, 2308 - 2331.

- Fowler, R. (1991). Language in the News: Discourse and Ideology in the Press. London: Routledge.

- Galasinska, A. Rev. of The Discursive Construction of National Identity. $2^{\text {nd }}$ ed. , by Ruth Wodak, Rudolf de Cillia, Martin Reisigl and Karin Liebhart, trans. Angelika Hirsch, Richard Mitten and J.W. Unger. Applied Linguistics 31 21 Dec. 2009: 166 - 168.

- Gibbs, R. W. Jr. (2002). A new Look at Literal Meaning in Understanding What Is Said and Implicated. Journal of Pragmatics, 34, 457 - 486.

- Goffman, E. (1967). Interaction Ritual: Essays on Face to Face Behavior. Garden City, New York.

- Grice, H. P. (1975). Logic and Conversation. In Peter Cole and Jerry L. Morgan, Eds. Syntax and Semantics 3: Speech Acts. $41-58$.

- Grundy, P. Doing Pragmatics. (1995). London: Edward Arnold.

- Hopper, P. J. , \& Traugott, E. C. (2003). Grammaticalization. Cambridge: Cambridge University Press.

- Horn, L. R. (1984). Towards a New Taxonomy of Pragmatic Inference: Qand R- Based Implicature. In D. Schiffrin, Ed. Meaning, Form, and Use in Context: Linguistic Applications. Washington, DC: Georgetown University Press, $11-42$.

- Horn, L. R. , and Gregory W. (Eds.). (2006). The Handbook of Pragmatics. Oxford: Blackwell.

- Jackson, H. (2007). Key Terms in Linguistics. London: Continuum.

- Kasper, G. Can Pragmatic Competence Be Taught? . (1997). 12 August 2017 


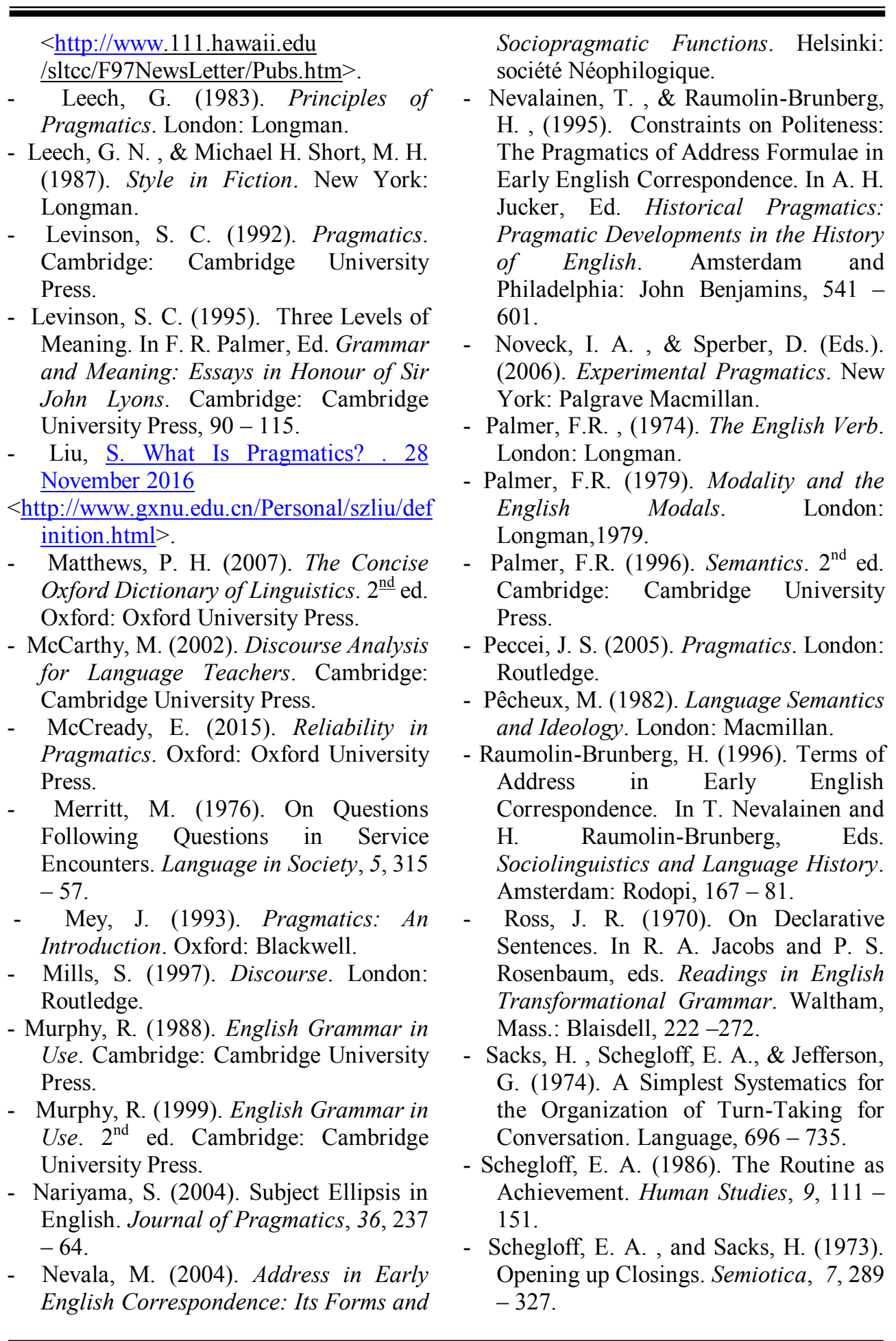


- Scrafton, S. (2009). Experimental Investigations into how Children and Adults Process the Implicature Associated with the Scalar Term Some. Doctoral Thesis. Durham University, 13 May 2017

$<$ http://etheses.dur.ac.uk/97/>.

- Sinclair, J. McH. , \& Coulthard, M. (1975). Towoards an Analysis of Discourse: The English Used by Teachers and Pupils. Oxford: Oxford University Press.

- Sperber, D. , \& Wilson, D. (1995). Relevance: Communication and Cognition. Oxford: Blackwell.

- Swan, M. (2009). Practical English Usage. Oxford. Oxford University Press.
- Thomas, J. (1995). Meaning in Interaction: An Introduction to Pragmatics. London: Longman.

- Watts, R. J. Politeness. (2004). Cambridge: Cambridge University Press.

- Wilson, D. (2010). Relevance Theory. In L. Cummings, ed. The Pragmatics Encyclopedia. London and New York: Routledge, 393 - 397.

- Yule, G. (2008). Pragmatics. Oxford: Oxford University Press.

- Yule, G. (2009). The Study of Language. $3^{\text {rd }}$ ed. Cambridge: Cambridge University Press.

- Yus, F. (2003). Humor and the Search for Relevance. Journal of Pragmatics, 35, 1295 - 1331. 